ASEAN Journal of Chemical Engineering 2021, Vol. X21, No. 1, $52-61$

\title{
Nanocellulose Production from Empty Palm Oil Fruit Bunches [EPOFB] Using Hydrolysis Followed by Freeze Drying
}

Irwan Hidayatulloh

Emmanuela Maria Widyanti

Endang Kusumawati

Lidya Elizabeth*

Department of Chemical Engineering, Politeknik Negeri Bandung, Jl. Gegerkalong Hilir, Ciwaruga, Bandung Barat, Jawa Barat 40559, Indonesia

*e-mail: lidya.elizabeth@polban.ac.id

Submitted 4 November $2020 \quad$ Revised 04 June $2021 \quad$ Accepted 10 June 2021

Abstract. Empty palm oil fruit bunches (EPOFB) are lignocellulose which is abundantly available in Indonesia. EPOFB has big potential as raw materials to substitute wood in nanocellulose manufacture. The production of nanocellulose from EPOFB consists of various stages, such as preparation by grinding and sizing, $\alpha$-cellulose isolation, acid hydrolysis, and freeze-drying. $\alpha$ cellulose isolate from EPOFB through delignification using $17.5 \% \mathrm{NaOH}(\mathrm{w} / \mathrm{v})$ at $80^{\circ} \mathrm{C}$ for 30 minutes and bleaching using $10 \% \mathrm{H}_{2} \mathrm{O}_{2}(\mathrm{v} / \mathrm{v})$ at $70^{\circ} \mathrm{C}$ for 15 minutes. The bleached cellulose was then hydrolyzed by acid hydrolysis process using $64 \% \mathrm{H}_{2} \mathrm{SO}_{4}$ for 45 minutes with temperature variations to determine the effect of temperature on the size of nanocellulose. Obtained nanocellulose then dried with the freeze-drying method at a temperature of $50^{\circ} \mathrm{C}$ for 6 hours. The nanocellulose morphology was characterized using SEM analysis, and FTIR analysis was done to determine the presence of cellulose and lignin. The smallest average diameter obtained at $50^{\circ} \mathrm{C}$ temperature is $86.8 \mathrm{~nm}$ with a $51.5-66.5 \mathrm{~nm}$ distribution range.

Keywords: Empty palm oil fruit bunches, Freeze-drying, Hydrolysis, Nanocellulose

\section{INTRODUCTION}

One of the major abundant resources of natural polymers is cellulose. It can be found in plants (such as wood and cotton), animals (such as tunicate and other marine animals that consist of carbohydrates and protein), and microbial species (such as amoeba and invertebrate) (Burhani and Septevani 2018, Moniri et al. 2017). Nowadays, applications from cellulose materials have already been developed due to their sustainability, renewability, and biodegradability (Padzil et al. 2020, Shanmugarajah et al. 2015). Cellulose is the biggest component arranged in plant cells that contained in plants cell around $25-30 \%$ of the plant's dry weight; the other component is hemicellulose and lignin (Tayyab et al. 2017). Cellulose is a glucose chain that becomes a linear chain and connected by $\beta-1,4$-glycosidic bonds. Cellulose can be divided into three types, namely $\alpha$-Cellulose, $\beta$-Cellulose, and $\gamma$ Cellulose (Widyanti et al. 2020). Based on the morphology and crystallinity, nanocellulose can be divided into two major categories. Cellulose nanocrystals (CNCs), this kind of nanocellulose have $2-30 \mathrm{~nm}$ in width and length range between 100 and $500 \mathrm{~nm}$ that formed from cellulose fibers hydrolysis. 
Meanwhile, cellulose nanofibrils (CMCs) are a type of nanocellulose with a diameter of less than $100 \mathrm{~nm}$ and varies from $100 \mathrm{~nm}$ to $2 \mu \mathrm{m}$. CMCs are commonly produced by mechanical treatment (Hastati et al. 2019). Nano cellulose is a value-added raw material because it can be used as a good quality of polymers fillers. By far, nanocellulose has better mechanical properties than ordinary cellulose. The mechanical properties of nanocellulose must have a large surface ratio, high air binding ability, high tensile strength, and very porous (Trache et al. 2020). These properties make nanocellulose a very good filler for a composite product. According to Dufresne (2017) adding wood base nanocellulose to a polymer matrix was significantly increased the tensile strength of the composite.

Recent research showed that various biomass had been used as raw material in the production of nanocellulose, such as sugarcane bagasse (Kumar et al. 2020, Wulandari et al. 2016), wood (Winter et al., 2020), cotton (Theivasanthi et al. 2018), wheat straw (Liu et al. 2019), etc. One of the potential abundant biomass resources is the empty palm oil fruit bunch (EPOFB). In 2017, Indonesia's oil palm plantations reached $14,048,722 \mathrm{Ha}$, while in 2018 , there was $14,327,093 \mathrm{Ha}$. The estimated area in 2019 was $14,677,560 \mathrm{Ha}$ made Indonesia the largest palm oil plantations in the world (Directorate General of Agricultural Product Processing and Marketing. 2019). Moreover, a large amount of EPOFB as palm oil industry waste is produced every year. In 2016, crude palm oil (CPO) production reached 32 million tons (Palm Oil, 2017). Meanwhile, 1 ton of CPO production produced 1.1 tons of EPOFB waste (Douglas et al. 2009). The sustainability of EPOFB feedstock will continue to increase along with the uplifting in crude palm oil
(CPO) production in Indonesia. Moreover, based on the chemical composition of EPOFB, its consist of lignin $>20 \%$, hemicellulose $>$ $25 \%$, cellulose $>35 \%$ and moisture content about > 5\% (Rame. 2018, Ramli et al. 2015, Widyanti et al. 2020). Thus, the high cellulose content in EPOFB can be used as feedstock for making nanocellulose.

Cellulose from EPOFB obtained through isolation includes delignification with bases $(\mathrm{NaOH})$ to remove hemicellulose and lignin, bleaching with $\mathrm{H}_{2} \mathrm{O}_{2}$ to purify the obtained cellulose, followed by acid hydrolysis. Several comprehensive studies had done to reduce the size of cellulose into nanoparticles by acid hydrolysis process (llyas et al. 2018, Kumar et al. 2020, Kusmono et al. 2020, Mehanny et al. 2021, Yang et al. 2017), strong acid like $\mathrm{H}_{2} \mathrm{SO}_{4}$ is commonly used to eliminate amorphous region in cellulose. But the process rarely has been able to produce nano-sized cellulose that has a diameter under $100 \mathrm{~nm}$. Therefore, additional processes need to be carried out, so the nano-sized cellulose can be achieved. It is done by freeze-drying. Freeze-drying (lyophilization) is one of the available methods that is considered the simplest and most versatile way to remove suspension water without reducing the initial volume. There are two main lyophilization processes: growth of ice crystals (frozen) by cooling the material below its eutectic point and sublimation of ice molecules (drying) that occurs when water in a solid state is converted to water vapor without passing through the liquid phase. (Voronova et al. 2012, Zimmermann et al. 2016). This study aims to obtain cellulose in nanoscale from EPOFB at range diameters: $10-100 \mathrm{~nm}$ by acid hydrolysis. Freeze-drying is used as an additional treatment for nanocellulose to reduce agglomeration. 
54 Nanocellulose Production from Empty Palm Oil Fruit Bunches (EPOFB) Using Hydrolysis Followed by Freeze Drying

\section{MATERIALS AND METHODS}

\section{Materials}

The empty palm oil fruit bunch (EPOFB) material was collected from Bogor Palm Oil Plantation. Chemical compound such as sodium hydroxide $(\mathrm{NaOH}, 17.5 \%(\mathrm{w} / \mathrm{v}))$, sulphuric acid $\left(\mathrm{H}_{2} \mathrm{SO}_{4}, 64 \%(\mathrm{~V} / \mathrm{v})\right)$ and hydrogen peroxide $\left(\mathrm{H}_{2} \mathrm{O}_{2}, 10 \%(\mathrm{v} / \mathrm{v})\right)$ glacial were purchased from Merck, and purified water. All those chemicals were used without any further purification.

\section{Apparatus}

The apparatus used in this work consists of the three-necked flask, freeze dryer, grinder, centrifuge, analytical balance, stirrer, water bath, hotplate, thermometer, and condenser.

\section{Procedure}

This study's extraction of nanocellulose was carried out through several stages, such as EPOFB grinding and sizing, $\alpha$-cellulose isolation, acid hydrolysis, centrifugation, and freeze-drying. The EPOFB ware ground and reduced their size into 200 mesh before the $\alpha$-cellulose isolate process. Loss on drying analysis was carried out to measure the moisture content of EPOFB. Analysis of moisture content is carried out by weighing the wet sample then heating it in the oven until the sample reaches an equilibrium weight. The amount of weight loss is the moisture content of the sample. The isolation of $\alpha$-cellulose itself consists of two steps, including delignification by adding $\mathrm{NaOH}$ $17.5 \%(\mathrm{w} / \mathrm{v})$ to $80^{\circ} \mathrm{C}$ for 30 minutes and the bleaching process by adding $\mathrm{H}_{2} \mathrm{O}_{2} 10 \%(\mathrm{v} / \mathrm{v})$ at $70^{\circ} \mathrm{C}$ for 15 minutes. The acid hydrolysis process is then carried out using a $64 \%(\mathrm{v} / \mathrm{v})$ $\mathrm{H}_{2} \mathrm{SO}_{4}$ solvent with a ratio between the sample weight and the volume of the $\mathrm{H}_{2} \mathrm{SO}_{4}$ solvent (1:10) to break the amorphous bond on cellulose. Variations of the hydrolysis process were carried out at temperatures $40^{\circ} \mathrm{C}, 45^{\circ} \mathrm{C}$, and $50^{\circ} \mathrm{C}$ for 45 minutes (Burhani and Septevani 2018; Wulandari et al. 2016). The acid hydrolysis product is then carried out in a centrifugation process with a speed of $4000 \mathrm{rpm}$ for 30 minutes to separate the sediment from the solution. The precipitated which has been separated was then dried using a freeze dryer at $-53^{\circ} \mathrm{C}$ for 7 hours. The obtained nanocellulose then characterized by SEM and FTIR method.

\section{Characterization Methods}

\section{SEM}

The morphology of nanocellulose was characterized using a scanning electron microscope (SEM) (Zeiss Evo 10) at $10 \mathrm{kV}$. The morphology image of the nanocellulose was taken at $10.00 \mathrm{~K} X$ magnification. Due to the unique chamber configuration, the sample was mounted on the sample holder and imaged directly without pretreatment, even in the hydrated sample. The diameter was determined with ImageJ software from the SEM images. This SEM analysis was carried out in the laboratory of the Department of Civil Engineering, Bandung State Polytechnic.

\section{FTIR}

The Fourier Transform Infrared Spectroscopy (FTIR) spectra of the raw EPOFB and nanocellulose were recorded on Bruker FTIR Alpha II Spectrometers at the laboratory of the Department of Chemical Engineering, Bandung State Polytechnic. First, the sample suspensions were filtrated and dried at ambient temperature before analyzed. The samples were put in a cell holder. Infrared spectra of each sample were measured in the wavelength range between 4000 to $500 \mathrm{~cm}^{-1}$. 


\section{RESULT AND DISCUSSION}

\section{Preparation Stage of Empty Palm Oil Fruit Bunches (EPOFB)}

In the preparation stage, empty palm oil bunches (EPOFB), which have been washed and dried for about two days, are reduced by using grinding and sizing to obtain a fine sample of 200 mesh size. At this stage, the moisture content obtained from EPOFB fibers and fine EPOFB were $9.18 \%$ and $6.9 \%$, respectively. Treated EPOFB was dried until the moisture content was less than $10 \%$ prior to usage. Figure 1 shows of EPOFB preparation stage.

Moreover, Functional group observations were made to determine the presence of cellulose content in fine EPOFB using the FTIR method, as shown in Figure 2.

FTIR analysis results show a wavelength number of $3321.61 \mathrm{~cm}^{-1}$ which indicates an $\mathrm{O}-\mathrm{H}$ stretching bond in the hydroxyl group, while the peak at $2849.60 \mathrm{~cm}^{-1}$ is the absorption area of $\mathrm{C}-\mathrm{H}$ stretching. The absorption peak around $1030.73 \mathrm{~cm}^{-1}$ is a C$\mathrm{O}-\mathrm{C}$ functional group of the pyranose ring, and the peak of $898.38 \mathrm{~cm}^{-1}$ is reflected $\beta-1,4$ Glycosidic functional group. The C-O stretching of hemicellulose is represented by the peak $1030.73 \mathrm{~cm}^{-1}$ and the board absorption in the range of $1200-1300 \mathrm{~cm}^{-1}$, an aromatic alkali skeletal vibration of group $\mathrm{C}=\mathrm{C}$ indicated that the fine EPOFB still contained lignin. Based on the results, the appearance of peaks on the $-\mathrm{OH}, \mathrm{C}-\mathrm{H}$, and $\mathrm{C}$ $C$ bonds indicates that EPOFB contains cellulose, hemicellulose, and lignin (Alves et al. 2015, Shanmugarajah et al. 2015).

\section{Isolation Stage of $\alpha$-Cellulose from Empty} Palm Oil Fruit Bunches

In the pretreatment, delignification and bleaching processes were carried out to isolate $\alpha$-cellulose. Delignification is a process to remove lignin between cells and in the cell walls through alkalizing treatment by using $17.5 \%(\mathrm{w} / \mathrm{v}$ ) of $\mathrm{NaOH}$ accompanied by stirring and heating at $80^{\circ} \mathrm{C}$ for 30 minutes. Alkaline treatment allows the delignification process, leading to swelling ordered surface with several cracks and empty lines that occur on the rise of the fiber (Burhani and Septevani. 2018).

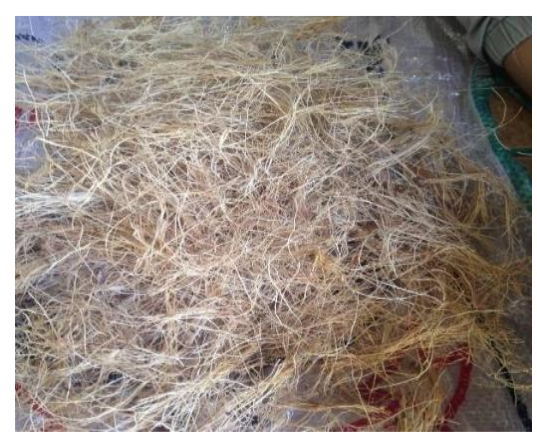

(a)

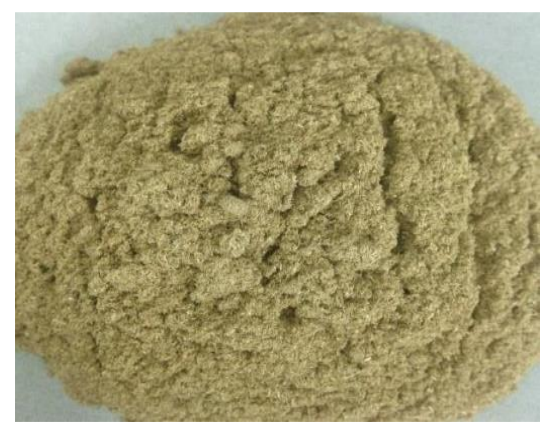

(b)

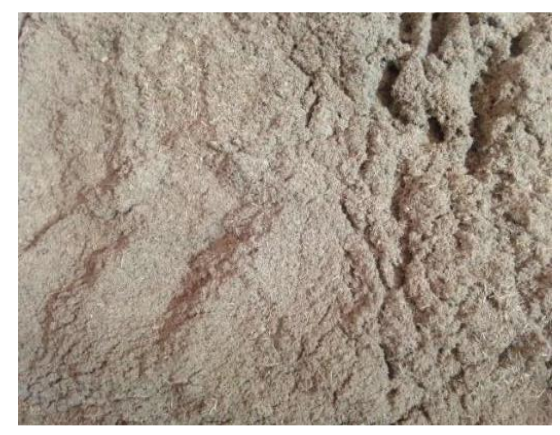

(c)

Fig. 1: (a) Dried EPOFB, (b) Grinded EPOFB, and (C) Fine EPOFB at 200 Mesh. 


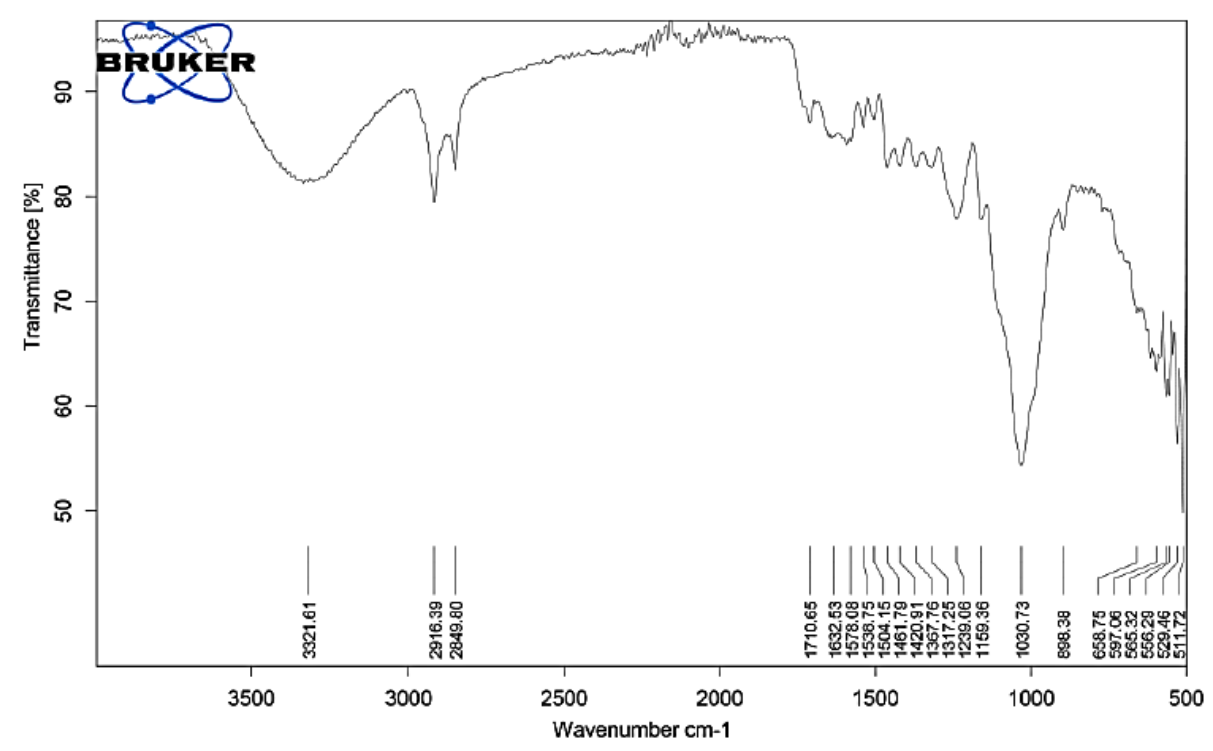

Fig. 2: FTIR of Fine EPOFB at 200 Mesh.

The results of the delignification process showed different colors between filtrate and residue. The residue is then added with waters and decanted for 24 hours until its form into three layers, the top layer is light brown foam, the middle layer is dark brown, lignin, and the third layer is light brown sediment. Next, the residue is rinsed using distilled water continuously until the $\mathrm{pH}$ is neutral, then filtering and drying for the following process. The EPOFB delignification result, which contains three layers of different colors, is shown in Figure 3.

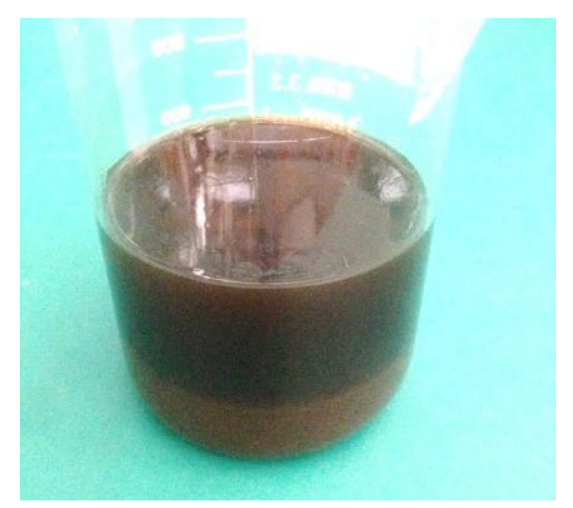

Fig. 3: Sample Results of the Delignification Process

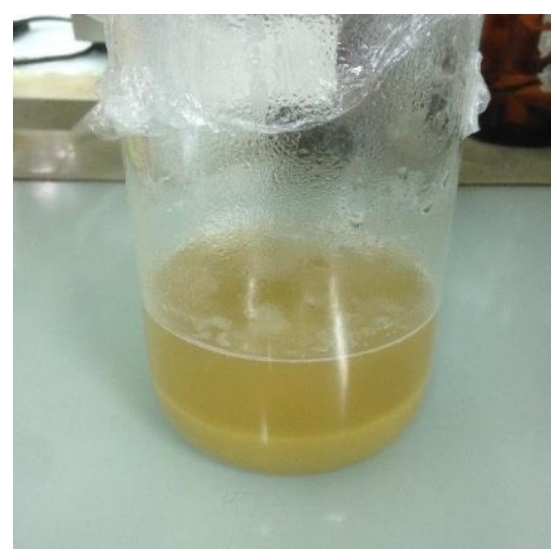

Fig 4: Sample Result of the Bleaching Process

This bleaching process was done to increase the cellulose while decrease lignin and hemicellulose content. Reactions of anion that produced hydrogen peroxide in alkaline solution with lignin lead remove most chromophoric groups (carbonyl and conjugated carbonyl groups and quinones) in the lignin molecule (Mussatto et al., 2008). The darker films created by the presence of lignin and provides unwanted physical and optical properties of nanocellulose. Hemicellulose, in the meantime, also reduces the individual fiber's resistance, which 
damages the mechanical properties of nanocellulose. For those reasons, both lignin and hemicellulose are needed to be removed from cellulose (Mussatto et al. 2008). Amount of $\mathrm{H}_{2} \mathrm{O}_{2} 10 \%(\mathrm{v} / \mathrm{v})$ was added to the treated solution accompanied by stirring and heating at $70^{\circ} \mathrm{C}$ for 15 minutes until its produce a lighter residue. The sample color changes from originally brown to yellow and can be seen in Figure 4.

The resulting residue was rinsed with distilled water through the neutralization process until a neutral $\mathrm{pH}$ was obtained. And then, it was filtered and dried for analysis using FTIR, SEM, and cellulose lignin content test. Figure 5 shows the result of the FTIR analysis of the analyzed sample from the bleaching process.

This FTIR result indicates that most hemicellulose and lignin content were removed after hydrolysis. However, it still contains them even in a small amount, proven by the absence of peak $1710.65 \mathrm{~cm}^{-1}$ and absorption peak $1225.80 \mathrm{~cm}^{-1}$, which relates to hemicellulose and lignin content. The peak 1710,65 $\mathrm{cm}^{-1}$ was the carbonyl/carboxyl peak associated with the conjugated carbonyl-carboxyl stretching. The result also strengthened by the SNI 0444: 2009 and SNI 0492: 2008 test to obtain the percentage of cellulose and lignin content, respectively. The yield was shown in Table 1 .

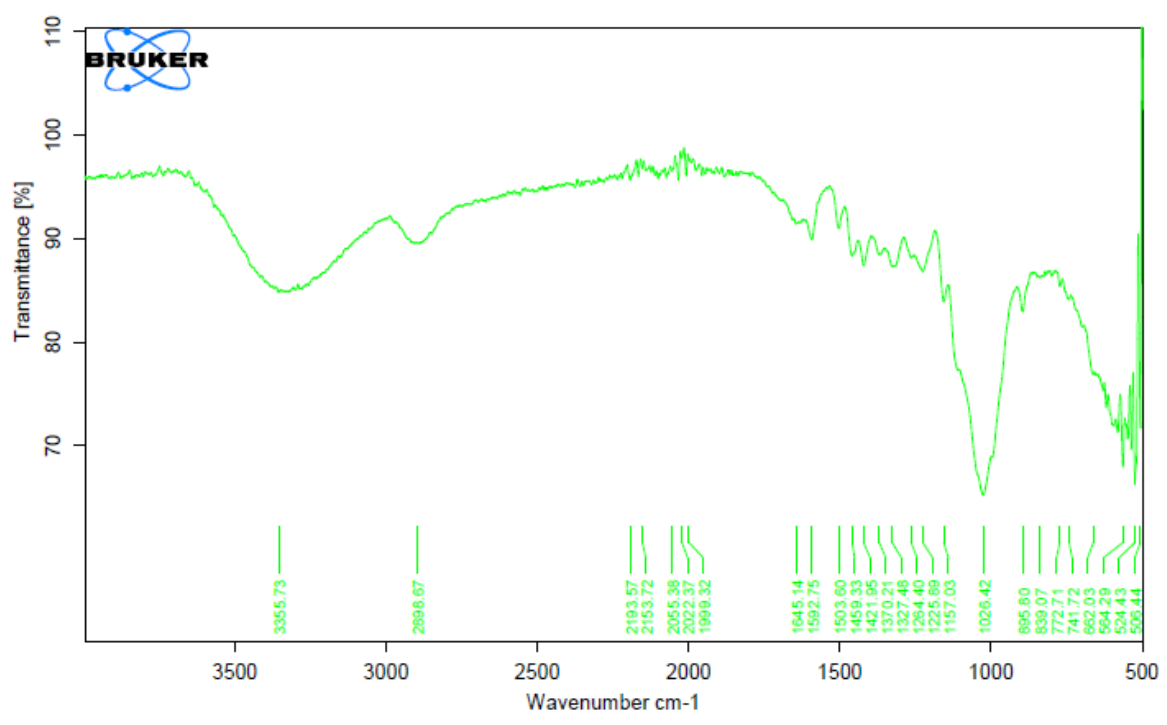

Fig. 5: FTIR Analysis of the Bleaching Process Result

Table 1: EPOFB Cellulose and Lignin Content After Bleaching and Hydrolysis Process

\begin{tabular}{c|c|c}
\hline Component & $\begin{array}{c}\text { a Raw } \\
\text { EPOFB (\%) }\end{array}$ & $\begin{array}{c}\text { Treated } \\
\text { EPOFB } \\
(\%)\end{array}$ \\
\hline Cellulose & $35,66-57,75$ & 93.88 \\
Hemicellulose & $6.61-15,96$ & - \\
Lignin & $21,27-36.68$ & 4.98 \\
\hline
\end{tabular}

(Source: ${ }^{\text {a. }}$ Widyanti et al. 2020)
Preparation of Nanocellulose using Acid Hydrolysis followed by Freeze-Drying Method

The preparation of nanocellulose from EPOFB was carried out by acid hydrolysis using $\mathrm{H}_{2} \mathrm{SO}_{4} 64 \%$ ( $\mathrm{v} / \mathrm{v}$ ) with mechanical treatment stirring and heating under temperature variations of $40^{\circ} \mathrm{C}, 45^{\circ} \mathrm{C}$, and $50^{\circ} \mathrm{C}$ for 45 minutes in a water bath. The characteristics of nanocellulose from acid 
58 Nanocellulose Production from Empty Palm Oil Fruit Bunches (EPOFB) Using Hydrolysis Followed by Freeze Drying

hydrolysis are influenced by several factors, including the source of cellulose, type of acid, acid concentration, reaction time, and temperature of hydrolysis. The acid hydrolysis treatment aims to break down the amorphous part of cellulose to reduce the

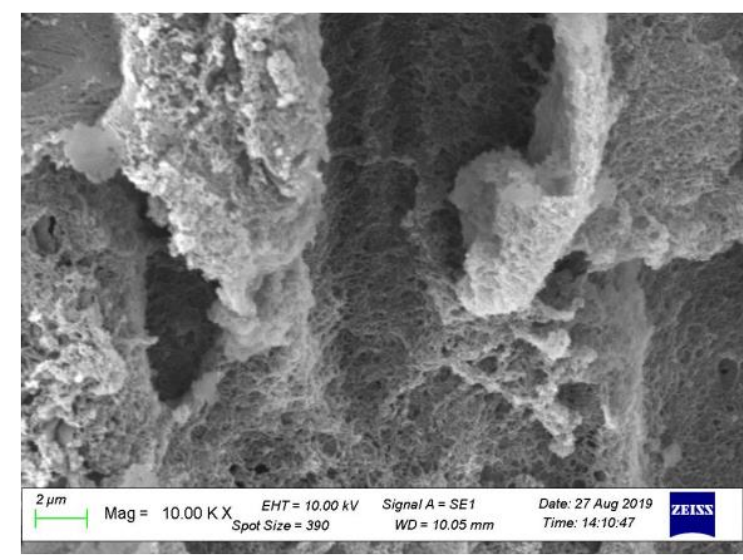

(a)

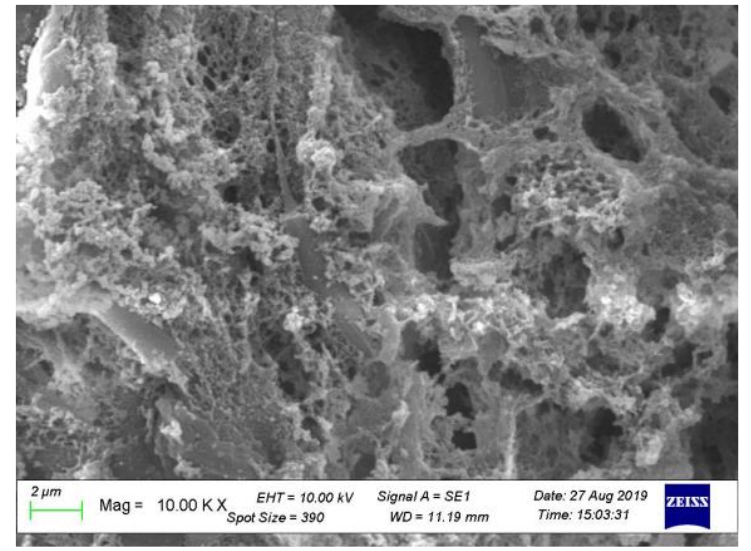

(b)

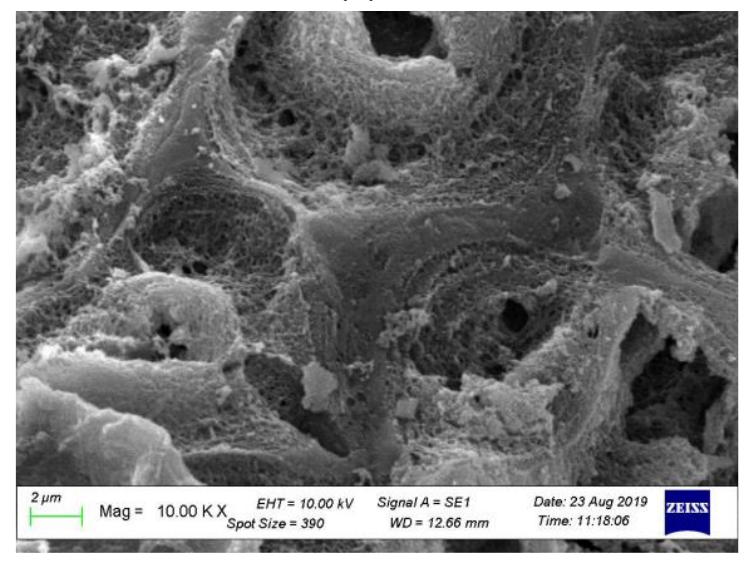

(c)

Fig. 6: (a) SEM figure of nanocellulose from EPOFB at $40^{\circ} \mathrm{C}$, (b) $45^{\circ} \mathrm{C}$, and (c) $50^{\circ} \mathrm{C}$ Hydrolysis Process Temperature Variations size of the fiber to nano size (Börjesson \& Westman, 2015).

After acid hydrolysis, the sample solution is neutralized to $\mathrm{pH}=7$, centrifuged with a rotating speed of $4000 \mathrm{rpm}$ for 30 minutes to obtain nanocellulose precipitates. Nanocellulose deposits were put into a $10 \mathrm{ml}$ sample into the freezer for 24 hours and continued with the freeze-drying process at a heating temperature of $53^{\circ} \mathrm{C}$ for 7 hours. The freeze-drying process has the purpose of eliminating the water content of nanocellulose, which has been frozen with the principle of sublimation. The drying process will reduce the aggregation of particles at nanocellulose. Moreover, obtained nanocellulose was tested using SEM to determine the morphology, particle size, pores, and particle shape of the material.

In Figures 6, the results of the SEM test for nano cellulose with temperature variations of $40^{\circ} \mathrm{C}, 45^{\circ} \mathrm{C}$, and $50^{\circ} \mathrm{C}$. Based on the result, nanocellulose fibers still experienced agglomeration. This agglomeration occurs due to the Van der Waals attractive force (ASTM Standard, 2004). The SEM results showed that the largest nanocellulose agglomeration was at a hydrolysis temperature of $40^{\circ} \mathrm{C}$. Meanwhile, at $45^{\circ} \mathrm{C}$ and $50^{\circ} \mathrm{C}$, the agglomeration has been reduced.

The average diameter obtained at temperature variations of $40^{\circ} \mathrm{C}, 45^{\circ} \mathrm{C}$, and $50^{\circ} \mathrm{C}$ were $109.2 \mathrm{~nm}, 95.7 \mathrm{~nm}$, and $86.8 \mathrm{~nm}$. With size distribution range of nanocellulose was 98.9-119.7 nm, 71.2-88.2 nm, 51.5-66.5 $\mathrm{nm}$, respectively. The results of the particle size analysis are shown in Figure 7.

From this temperature variation, the higher temperature during the acid hydrolysis process, the smaller diameter of the nanocellulose produced. If compared with the research performed by 


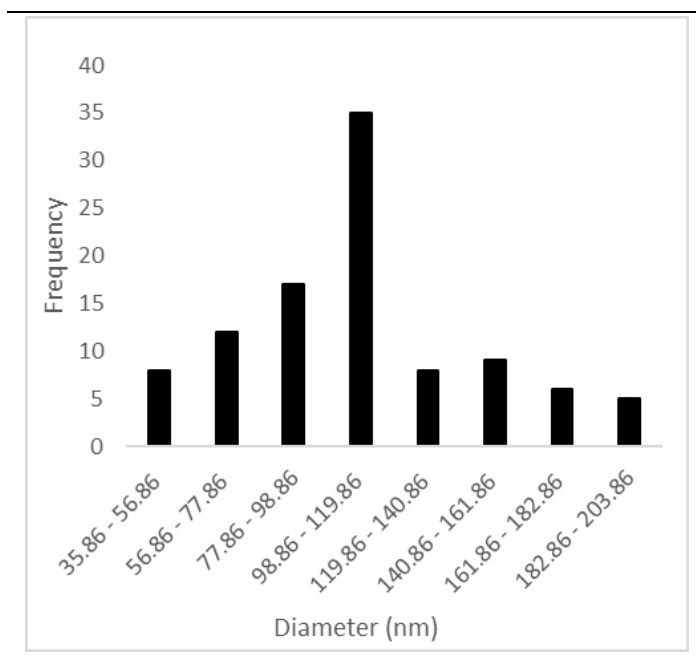

(a)

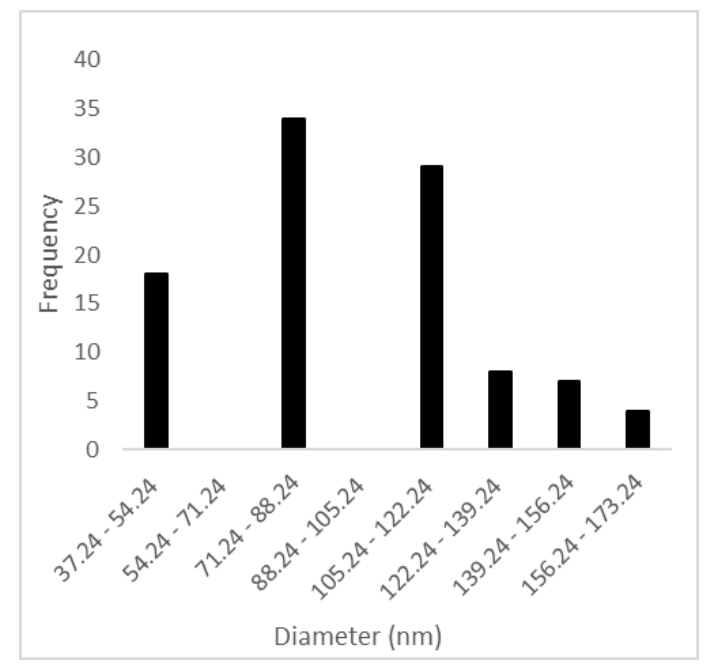

(b)

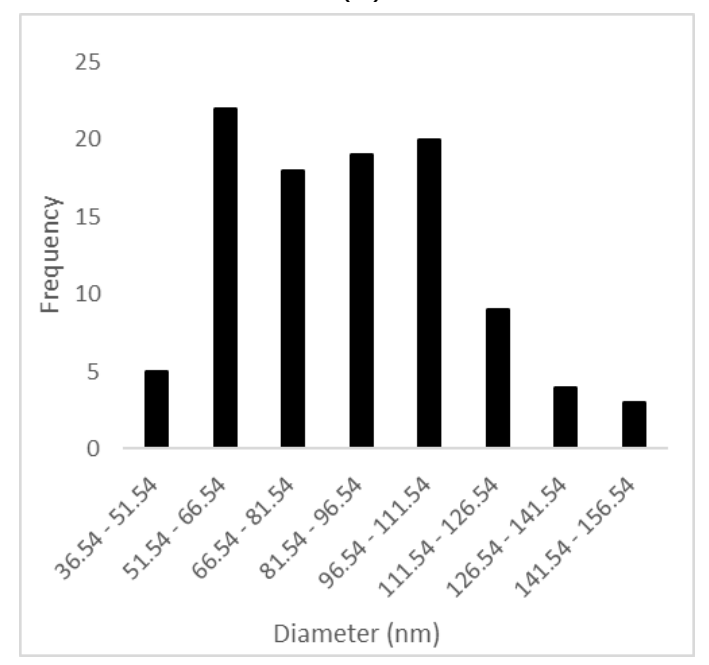

(c)

Fig. 7: Particle Size Distribution Range of Nanocellulose at $40^{\circ} \mathrm{C}$, (b) $45^{\circ} \mathrm{C}$, and (c) $50^{\circ} \mathrm{C}$ Hydrolysis Process Temperature Variations
Shanmugarajah et al. (2015) and by Septevani et al. (2020), the resulting diameter without freeze-drying is $499.2 \mathrm{~nm}$ and about 123.3 $\mathrm{nm}$, respectively. It means the effect of the freezing process on the resultant diameters is significant.

\section{CONCLUSIONS}

Nanocellulose was successfully isolated from EPOFB using hydrolysis of sulfuric acid followed by freeze-drying to get over the aggregation of particles that might happen. The presence of nanocellulose was characterized using FITR, while the morphology of nanocellulose was characterized using the SEM method. From the result of this work, the average diameter of nanocellulose was obtained. Based on the temperature variations of hydrolysis at $40^{\circ} \mathrm{C}$, $45^{\circ} \mathrm{C}$, and $50^{\circ} \mathrm{C}$, the average diameters are $109.2 \mathrm{~nm}, 95.7 \mathrm{~nm}$, and $86.8 \mathrm{~nm}$, with particle size distribution ranges are $98.9-119.7 \mathrm{~nm}$, $71.2-88,2 \mathrm{~nm}, 51.5-66.5 \mathrm{~nm}$, respectively. The higher the temperature during the hydrolysis process, the smaller of nanocellulose average diameter produced.

\section{ACKNOWLEDGMENT}

This work was funded by DIPA of Politeknik Negeri Bandung contract no. B/186.56/PL1.R7/PG.00.03/2020. The authors would like to give appreciation to Riski Eka Fahira and Muthia Amanda Gildelarosa for their efforts in experimental works.

\section{REFERENCES}

1. Alves, L., Medronho, B., Antunes, F. E., Fernández-García, M. P., Ventura, J., Araújo, J. P., Romano, A., \& Lindman, B. (2015). "Unusual extraction and characterization of nanocrystalline 
60 Nanocellulose Production from Empty Palm Oil Fruit Bunches (EPOFB) Using Hydrolysis Followed by Freeze Drying

cellulose from cellulose derivatives". Journal of Molecular Liquids, 210, 106112.

2. Börjesson, M., \& Westman, G. (2015). "Crystalline Nanocellulose Preparation, Modification, and Properties". Cellulose - Fundamental Aspects and Current Trends.

3. Burhani, D., \& Septevani, A. A. (2018). "Isolation of nanocellulose from oil palm empty fruit bunches using strong acid hydrolysis". AIP Conference Proceedings, 2024.

4. Direktorat jendral Pengolahan dan Pemasaran Hasil Pertanianl. (2019). Pedoman Pengolahan Limbah Industri Kelapa Sawit. In Departemen Pertanian.

5. Douglas, S., Anne, C., Erik, M., Meine, van N., Joanne, G., Jacqui, S.-G., Karah, W., \& Markku, K. (2009). "The impacts and opportunities of oil palm in Southeast Asia". In Occasional Papers. Center for International Forestry Research (CIFOR).

6. Dufresne, A. (2017). "Cellulose nanomaterial reinforced polymer nanocomposites". Current Opinion in Colloid and Interface Science, 29, 1-8.

7. Hastati, D. Y., Hambali, E., Syamsu, K., \& Warsiki, E. (2019). "Preparation and Characterization of Nanocelluloses from Oil Palm Empty Fruit Bunch Cellulose". Journal of the Japan Institute of Energy, 98(8), 194-201.

8. Ilyas, R. A., Sapuan, S. M., \& Ishak, M. R. (2018). "Isolation and characterization of nanocrystalline cellulose from sugar palm fibers (Arenga Pinnata)". Carbohydrate Polymers, 181, 1038-1051.

9. Kumar, A., Singh Negi, Y., Choudhary, V., \& Kant Bhardwaj, N. (2020). "Characterization of Cellulose Nanocrystals Produced by AcidHydrolysis from Sugarcane Bagasse as Agro-Waste". Journal of Materials Physics and Chemistry, 2(1), 1-8.

10. Kusmono, Listyanda, R. F., Wildan, M. W., \& Ilman, M. N. (2020). "Preparation and characterization of cellulose nanocrystal extracted from ramie fibers by sulfuric acid hydrolysis". Heliyon, 6(11), e05486. $\mathrm{L}$

11. iu, Z., He, M., Ma, G., Yang, G., \& Chen, J. (2019). "Preparation and characterization of cellulose nanocrystals from wheat straw and corn stalk". Palpu Chongi Gisul/Journal of Korea Technical Association of the Pulp and Paper Industry, 51(2), 40-48.

12. Mehanny, S., Abu-El Magd, E. E., Ibrahim, M., Farag, M., Gil-San-Millan, R., Navarro, J., El Habbak, A. E. H., \& El-Kashif, E. (2021). "Extraction and characterization of nanocellulose from three types of palm residues". Journal of Materials Research and Technology, 10, 526-537.

13. Moniri, M., Moghaddam, A. B., Azizi, S., Rahim, R. A., Ariff, A. Bin, Saad, W. Z., Navaderi, M., \& Mohamad, R. (2017). "Production and status of bacterial cellulose in biomedical engineering". Nanomaterials, 7(9), 1-26.

14. Mussatto, S. I., Rocha, G. J. M., \& Roberto, I. C. (2008). "Hydrogen peroxide bleaching of cellulose pulps obtained from brewer's spent grain". Cellulose, 15(4), 641-649.

15. Padzil, F. N. M., Lee, S. H., Ainun, Z. M. A. ari, Lee, C. H., \& Abdullah, L. C. (2020). "Potential of oil palm empty fruit bunch resources in nanocellulose hydrogel production for versatile applications: A review". Materials, 13(5).

16. Palm Oil.

(2017).

https://www.indonesia-

investments.com/business/commoditie s/palm-oil/item166

17. Rame. (2018). "Oil Palm Empty Fruit Bunches (OPEFB): Existing Utilization and Current Trends Biorefinery in Indonesia". E3S Web of Conferences, 31, $1-5$.

18. Ramli, R., Junadi, N., Beg, M. D. H., \& Yunus, R. M. (2015). "Microcrystalline Cellulose (MCC) From Oil Palm Empty Fruit Bunch (EFB) Fiber via Simultaneous Ultrasonic and Alkali Treatmen"t. 9(1), 811.

19. Septevani, A. A., Rifathin, A., Sari, A. A., 
Sampora, Y., Ariani, G. N., Sudiyarmanto, \& Sondari, D. (2020). "Oil palm empty fruit bunch-based nanocellulose as a super-adsorbent for water remediation". Carbohydrate Polymers, 229 (May 2019), 115433.

20. Shanmugarajah, B., Kiew, P. L., Chew, I. M. L., Choong, T. S. Y., \& Tan, K. W. (2015). "Isolation of Nanocrystalline Cellulose (NCC) from palm oil empty fruit bunch (EFB): Preliminary result on FTIR and DLS analysis". Chemical Engineering Transactions, 45(October), 1705-1710.

21. Tayyab, M., Agriculture, F., Noman, A., Waheed, S., \& Agriculture, F. (2017). "Bioethanol production from lignocellulosic biomass by environment-friendly pretreatment methods: A review". Applied Ecology and Environmental Research, December.

22. Theivasanthi, T., Anne Christma, F. L., Toyin, A. J., Gopinath, S. C. B., \& Ravichandran, R. (2018). "Synthesis and characterization of cotton fiber-based nanocellulose". International Journal of Biological Macromolecules, 109, 832836.

23. Trache, D., Tarchoun, A. F., Derradji, M., Hamidon, T. S., Masruchin, N., Brosse, N., \& Hussin, M. H. (2020). "Nanocellulose: From Fundamentals to Advanced Applications". In Frontiers in Chemistry (Vol. 8, Issue May).

24. Voronova, M. I., Zakharov, A. G., Kuznetsov, O. Y., \& Surov, O. V. (2012). The effect of drying technique of nanocellulose dispersions on properties of dried materials. Materials Letters, 68, 164-167.

25. Widyanti, E. M., Kusumawati, E., Regiana, A., \& Suminar, D. R. (2020). "Production Nanocellulose from Raw Materials For Oil Palm Empty Bunches (TKKS) with Hydrolysis and Freeze Drying Methods". IOP Conf. Series: Materials Science and Engineering, 742(012033).

26. Winter, A., Arminger, B., Veigel, S., Gusenbauer, C., Fischer, W., Mayr, M., Bauer, W., \& Gindl-Altmutter, W. (2020).
"Nanocellulose from fractionated sulfite wood pulp". Cellulose, 27(16), 93259336.

27. Wulandari, W. T., Rochliadi, A., \& Arcana, I. M. (2016). "Nanocellulose prepared by acid hydrolysis of isolated cellulose from sugarcane bagasse". IOP Conference Series: Materials Science and Engineering, 107(1).

28. Yang, X., Han, F., Xu, C., Jiang, S., Huang, L., Liu, L., \& Xia, Z. (2017). Effects of preparation methods on the morphology and properties of nanocellulose (NC) extracted from corn husk. Industrial Crops and Products, 109(August), 241-247.

29. Zimmermann, M. V. G., Borsoi, C., Lavoratti, A., Zanini, M., Zattera, A. J., \& Santana, R. M. C. (2016). "Drying techniques applied to cellulose nanofibers". Journal of Reinforced Plastics and Composites, 35(8), 682-697. 